\title{
放射線重合による塩化カリウムを含んだポリメチル・ メタクリレートカブセルの調製とその薬剂徐放性
}

\author{
吉田 勝*1 ·熊倉 稔*1 ・嘉说 稒*1
}

（受付 1978 年 7 月 26 日・籍查終了 1978 年 8 月 25 日）

\begin{abstract}
要旨埴化カリウムを含む多扎啠カプセルは，ポリエチレングリコール

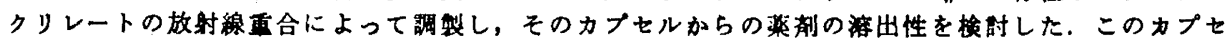
ルの多孔算梏はメチルメタクリレートとポリエチレンダリコール； 600 の組成によってコントロー ルできる.カブセルから溶出した莱谚妟を時間の平方根を网数としてプットしたところ，直線関倸

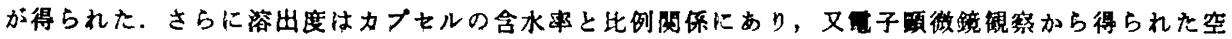
れ事 (porosity) とも同栚な関保が琶められた。
\end{abstract}

\section{1 楮 夏}

医薬品の高分子マトリックスによる包括が消化管刺潄 物質の被覆，安定化および楽用の容出の持続化などを目 的として広く研究されているいー4).

著者らは放射線重合を利用ら)して，醉点，菌体など生 物活性体の包括固定の研究(の)、で進めているか，放射線 法によれば，(1) 比教的低温で固定化ができるので生物 活性体の熱や放射線による失活が少ない，(2) 触媒など の不純物が混入しない，(3) 制菌作用があるなどの利点

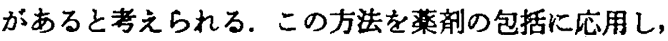
調製された徐放性を有するポリマーカブセルの調製が可 能であることを見いだしだ． 本報告では，その一頊と して多孔質構造調製郕としてのポリエチレンタリコール \#600 存在下に, メチルメタクリレートの放射線重合に 上り, 低カリウム血症の治療に用いられる塩化カリウム を包括し，得られたカブセルの多孔質粠造と溶出性の閏 伱について検討した結果を報告する。

\section{2 实騸}

\section{1 试涤}

市眅の塩化カリウム $(\mathrm{KCl})$ は 40 メッシュ以下の粉末

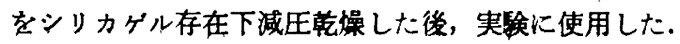
メチルメタクリレートモノマー (MMA) は東京化成 (株)製を常法に従って精製し，ポリエチレンクリコール \#600 (PEG 600) は和光純薬工業(株) 制をそのまま実験 に使用した。

*1 日本原子力研究所高绮研究所（四370-12 高绮市綿 面町 1233)

\section{2 カブセル（臬合物）の神斐}

内径 $14 \mathrm{~mm} \phi$ の平底ガラスフンプル中に $600 \mathrm{mg}$ の $\mathrm{KCl}$ を添加し，その後, 種々の組成の MMA-PEG 600 混合液をメスピヘットで注入した。この場合，フン ブル中の $\mathrm{KCl}$ を完全に浸せきするために, $0.5 \mathrm{ml}$ の混 合液が必要であり，それによって見挂け上， $\mathrm{KCl}$ の均

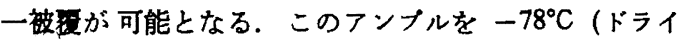
アイスとメタノール使用) の温度下で数回脱気 $\left(10^{-4}\right.$ $\mathrm{mmHg})$ L， ${ }^{80} \mathrm{Co}$ からの $\gamma$ 線を線量率 $5 \times 10^{5} \mathrm{R} / \mathrm{h}$, 照 射時間 $8 \mathrm{~h}$, 照射温度 $25^{\circ} \mathrm{C}$ の条件下で照射した. $\mathrm{KCl}$ と PEG 600 を含有した平底円筒状の直径 $14 \mathrm{~mm} \phi$, 高 さ $4 \mathrm{~mm}$ の硬い MMA ポリマー (PMMA) カプセル が得られた．カブセルの見掛けの表面積は $4.84 \mathrm{~cm}^{2}$ で あった.

\section{3 溶出詩儌}

溶出試虖仕 United States Pharmacopeia XIX に準 じ，富山産業(株) 製の TR-5S 型溶出試験器を用い， ： スケット回転数は $100 \mathrm{rpm}$ で， $37 \pm 0.5^{\circ} \mathrm{C}$ に維持した 佰温槽中で行った．容出媒体として pH 6.0 の蒸留水， $1000 \mathrm{~m} l$ を用いた. 溶出した $\mathrm{KCl}$ 量は䅅時的に $10 \mathrm{~m} l$ の溶出媒体を採取し，千オシフン酸水銀法9,10)によって 発色させ，(株)島津製作所製ダブルビーム，UV-200 型 分光光度計を用いて比色定量することによって求めた。

\section{4 カブセル中の多孔贾排造の測定}

PEG 600 によって PMMA カブセル中に形成された 多孔質橎造は日本電子光学(株) 製, JSM-U3 型走查電

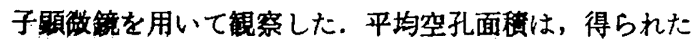
䫒徽箁写真から直接読み取り, 平均空孔径 $\left(D_{\mathrm{av}}\right)$ および 空孔事 $\left(W_{\mathrm{a}}{ }^{\prime}\right)$ を算出した。 


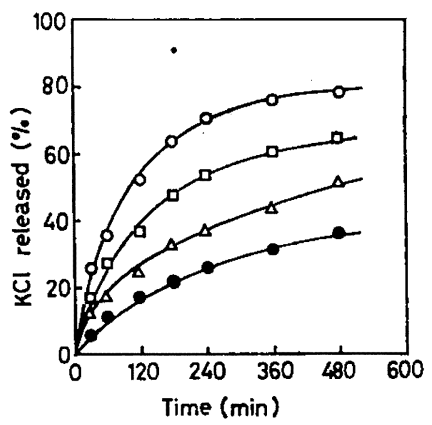

Fig. 1. Relationship between the release of drug in percent from polymer-drug copsule comprising $600 \mathrm{mg}$ of $\mathrm{KCl}$ and the time. Composition; (O) 30\%MMA-70\%PEG 600, (D) 50\% MMA-50\%PEG 600, ( $\triangle)$ 70\%MMA-30\%PEG 600, (๑) 100\%MMA.

$$
D_{\mathrm{av}}(\mu)=2 \times\left\{\frac{1 \mathrm{~cm}^{2} \text { 当たりの平均空孔面程 }}{\left(1 \mathrm{~cm}^{2} \text { 当たりの空孔数 }\right) \times \pi}\right\}^{1 / 2}
$$

$$
\begin{aligned}
& W_{a}^{\prime}(\%) \\
& \text { 顠致鏡によって覞察された空孔部分の }
\end{aligned}
$$

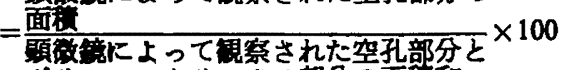

$$
\begin{aligned}
& \text { ポリーマトリックス部分の面称和 }
\end{aligned}
$$
取った。

一方, 空孔数 $\left(N_{\mathrm{p}}\right)$ む, 又, 直接䫒徽鏡写真から読み

\section{3 结果と考腺}

\section{1 多平 PMMA カブセルからの水中への $\mathrm{KCl} の$} 溶出

得られた多孔筫 PMMA カブセルからの $\mathrm{KCl}$ の溶出 挙動を Fig. 1 に示す. $\mathrm{KCl}$ 溶出量は MMA 㳻度の減 少とともに增加する傾向を示した。 50\%MMA 䙉度で のカブセルからの溶出曲線は市肘の $\mathrm{KCl}$ 徐放化錠㓣の それとよく一政し11), 又, moderate type のポリマー カブセルであることが分かった22.

\section{2 多孔楽カブセルからの $\mathrm{KCl}$ の溶出機苝}

ポリマーカブセル中に分散し，その容出がマトリック

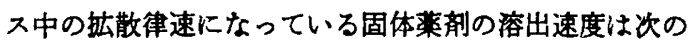
ように表せる ${ }^{18) \sim 18)}$.

$$
Q=\left(2 A-C_{\mathrm{n}}\right) \sqrt{\frac{D t}{1+\frac{2\left(A-C_{\mathrm{B}}\right)}{C_{\mathrm{B}}}}}
$$

ここで，Qは時間 $t$ Kおけるカブセルの単位表面㮴当た

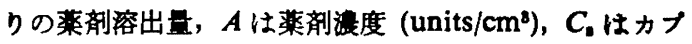
セル中の薬剤溶解度 (units $/ \mathrm{cm}^{8}$ )，D注カフセル中の薬 凨の拡散係数を示す。

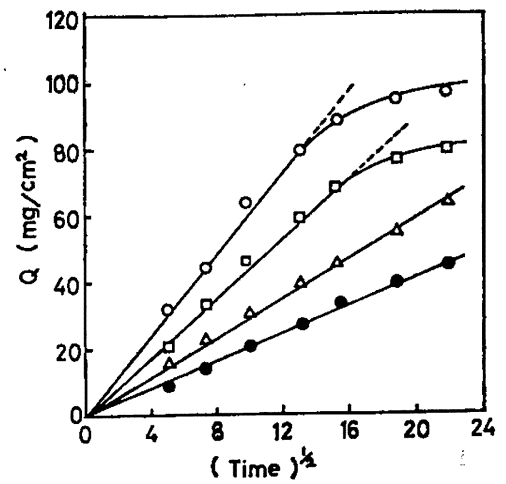

Fig. 2. Linear relationship between the cumulative amount of $\mathrm{KCl}$ released $(Q)$ per unit surface area of capsule and the square root of time. The plot is based on the data in Fig. 1.

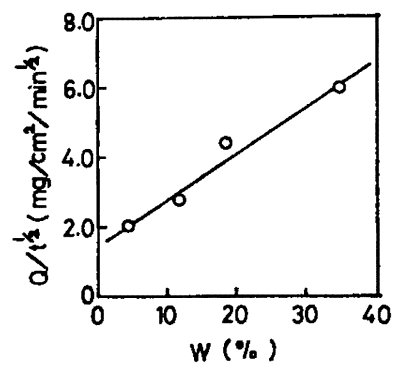

Fig. 3. Relationship between the flux of $\mathrm{KCl}$ release $\left(Q / t_{1 / 2}\right)$ and the water content $(W)$ of capsule.

$A \gg C_{8}$ の場合，(3) 式は（4) 式のよ5に近似できる.

$$
Q=\sqrt{2 A D C_{1} t}
$$

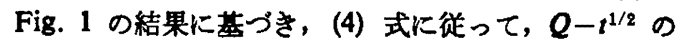

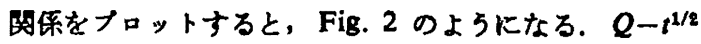
の成係は，いずれも原点を通る直線になった，それゆ え,このカブセルからの $\mathbf{~ K C l}$ の浴出は，抝散律速 (diffusion-controlled release) となっていると考えられ た.この場合，得られたカブセルは PEG 600 によって 多孔筫粗造を与えられており，このカブセルからの KCl の溶出且牥孔筫構造中の空孔率 (porosity) に依存して いると考えられる. この因子の影零について含水率 $(W)$ の変化から検討を試みた．含水状態でのカブセル中の空 孔率は，含水率を尺度として，(5) 式として表せる。

$$
W(\%)=\frac{W_{W}}{W_{W}+W_{p}} \times 100
$$

ここで，W $W_{\mathrm{p}}$ は水により $\mathrm{KCl}$, PEG 600 を完全に溶出 させた上で站嬠した PMMA カブセルの重量であり，

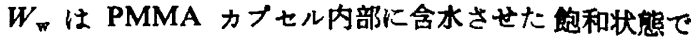




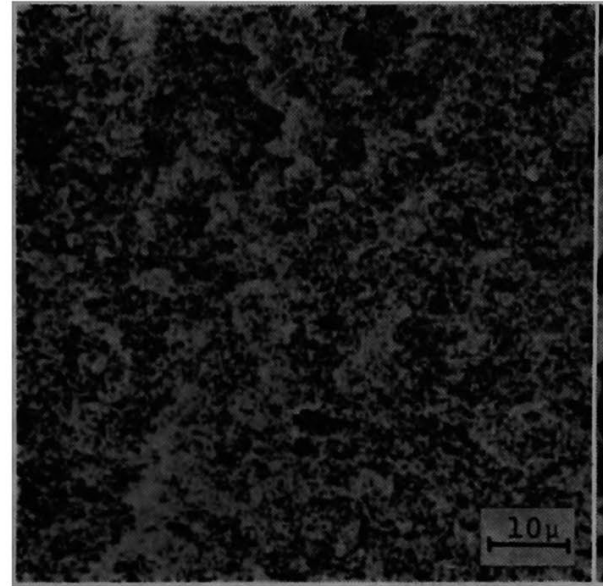

(a)

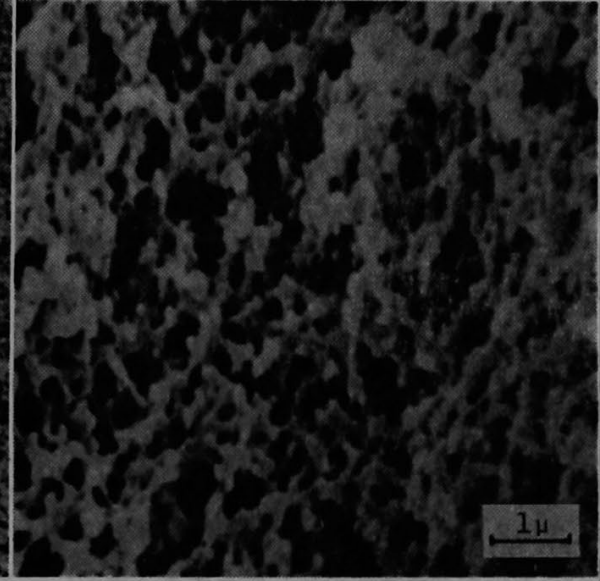

(b)

Fig. 4. Scanning electron microphotographs of porous structure in the capsule of $30 \%$ MMA$70 \%$ PEG 600 system. (a) $\times 1000$, (b) $\times 10000$.

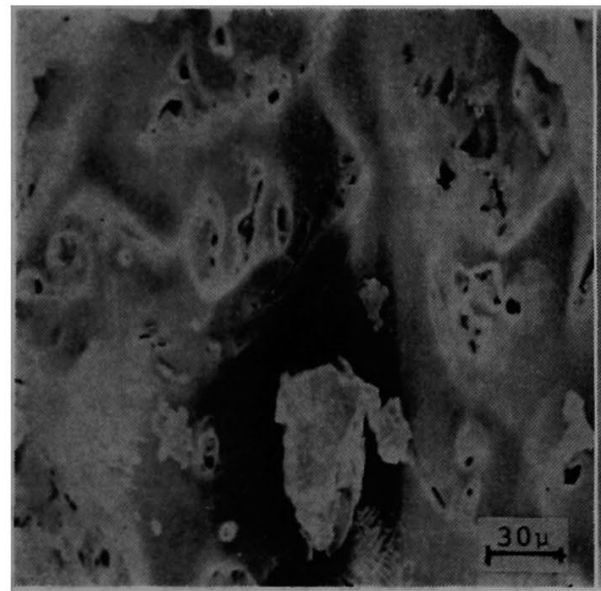

(a)

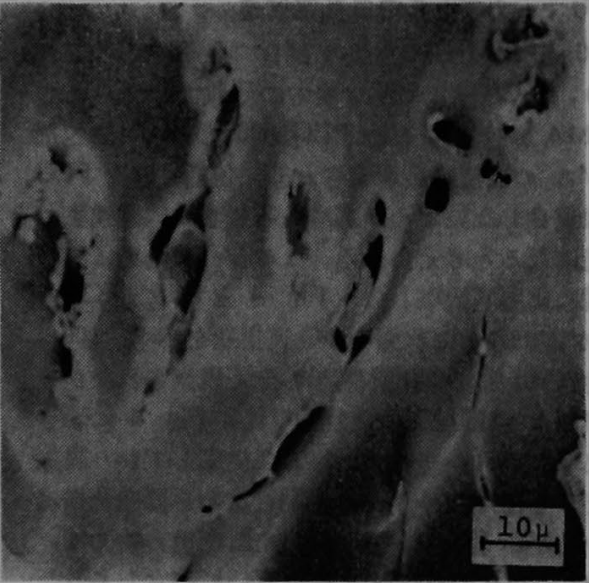

(b)

Fig. 5. Scanning electron microphotographs of porous structure in the capsule of $70 \%$ MMA$30 \%$ PEG 600 system. (a) $\times 300$, (b) $\times 1000$.

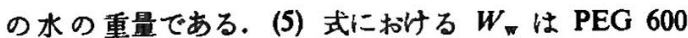
によって形成された空孔が含水した部分, PMMA 自体 が含水した部分， $\mathrm{KCl}$ が溶出することによって形成さ れた空孔が含水した 部分から成る.このカプセルの場 合, 乾燥した PMMA カプセル重量 $\left(W_{\mathrm{p}}\right)$ を $1 \mathrm{~g}$ と仮 定すれば, 30, 50, 70, 100\% MMA 濃度で作ったカプ セルに拈ける $W_{\mathrm{W}}$ は，各々 $0.53,0.23,0.13,0.05 \mathrm{~g}$ となる.この数值は PEG 600 濃度が $W_{\text {、 }}$ に大きい影留 を与え，実質的に水で置換されるよ5な空孔を作ってい ることを示している. 一方, PMMA マトリックス自体 が含水した水の重量は $0.03 \mathrm{~g}$ であるから，100\%MMA 濃度 $\left(\mathrm{KCl}\right.$ を含む系) における $W_{\mathrm{w}}$ より， $\mathrm{KCl}$ が溶出
することにより增加した水の重量は $0.02 \mathrm{~g}$ になる、こ の数値仕 $\mathrm{KCl}$ の添加量に比へ極くわずかである. 又,

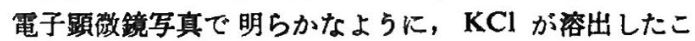
とによる空孔はほとんど認められていない(Fig. 5).こ のことから， $\mathbf{K C l}$ が非常に細かく分散しており，から 水によって置換されないよらな形によって溶出していく むのと考えられる.

Fig. 2 に打ける直線勾配から求めた溶出度 $Q / t^{1 / 2}$ と (5) 式からの含水率 (W) の関係を Fig. 3 に示した. $Q / t^{1 / 2}$ は $W$ の增加に伴い直線的に增加した.この結果 から， KCl の溶出は PEG 600 によって形成された空 孔が含水した部分, すなわち空孔率に依存していること 
が分かる、このような㑯向は低温放舺蜜至合によって得 たポリマーカブセルの場合についても認められてい る $^{16)}$.

本実験において， $\mathrm{KCl}$ のカプセル中への初仕込み 濩度を $A=1185 \mathrm{mg} / \mathrm{cm}^{8}$, PMMA カブセル自体の和

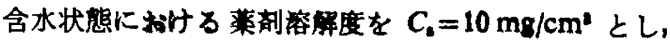
Fig. 2 の結果に従い(4) 式を用いて $D$ を而出した。 30，50，70，100\%MMA 瀑度で作られたカプセルにお けるマトリックスの飽和含水状热での Dは，それぞれ $1.52 \times 10^{-8}, 0.82 \times 10^{-8}, 0.37 \times 10^{-8}, 0.17 \times 10^{-8} \mathrm{~cm}^{2} /$ min である. PEG 600 の洨度が 70\% (30\%MMA

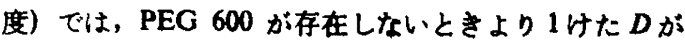

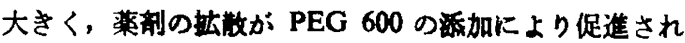
ることを示している.これはスポンジ棈造中のマトリッ クスの膜原が PEG 600 港度が大きいはどらすくなり， 見烓け上 over all の $D$ が增加すること, PEG 600 源 度が大きい任ど空孔の連緒化 (Fig. 4) が起こることな どが原因していると考えられる.

\section{3 ポリマーカプセルの多孔篗造}

PEG 600 と MMA は任恙の割合で混合することが 可能であり， $\mathbf{K C l}$ はこの混合度中に分散させた。この 状態で MMA が重合すると PEG 600 と KCl を包括 した PMMA の被㖇点が形成される，包括された PEG

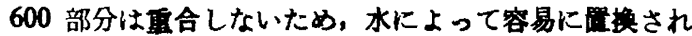
多孔質棈造になると考えられる。この多孔質棈造は走査 電子昰微鏡に上って誢察した. Fig. 4 と 5 K $\mathrm{KCl}$ と PEG 600 を容出させた状留の多孔質满造を示寸. $100 \%$ MMA 浱の坦合，多孔筫措造は全く鼠察されなかっ た. 50\%MMA 港度以下の复合物では，Fig. 4 に示さ れているよらに小さい空孔が密集して生成しておりり陆妾

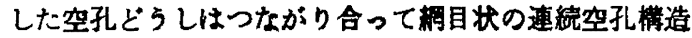
を示していわが，50\%MMA 港度以上の合合物では， Fig. 5 から，空孔の数は娍少し，互いに接合しあ5こ とが少なく独立に存在しキャピラリー構造をもってい ることが分かった. いずれの場合も空孔は姁等にカプセ ル内部に分布している.このような多孔質棈造は室温で の放射線重合で調製したカブセルの特改の一つであり， 低温放射線重合で調制したカブセルでは，空孔部分はモ ノマー度のいかんにかかわらず独立した空孔棤造で， かつ球状空孔構造を示す ${ }^{18)}$.この場合，キャビラリー， むしくは網目状棈造をすつ室温画合物からの莱剂の溶出 速度は球状空孔棈造をむつ低温重合物からのそれに比べ て，見挂け大きい。

Fig. 6 の結果から, 空孔径 $\left(D_{\mathrm{av}}\right)$ は MMA 浓度が增 加するはど大きくなり, 空孔数 $\left(N_{\mathrm{p}}\right)$ は诚少する㑯向が

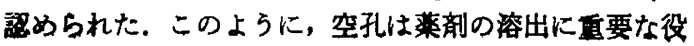
缡を果していることが明らかであるが，MMA 港度の

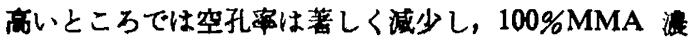

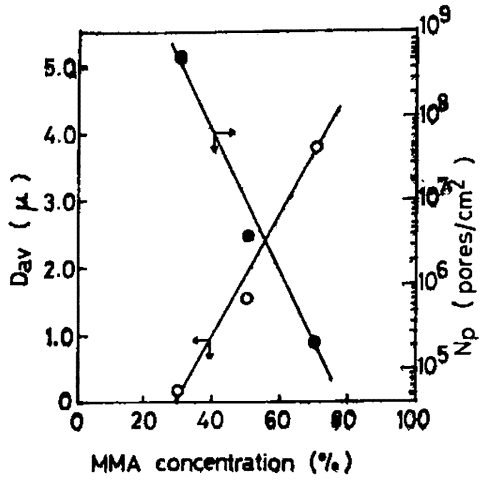

Fig. 6. Relationship between the pore factors in the capsule and the MMA monomer concentration.

度では空孔が存在しないにむかかからず客出が起こるこ とから, PMMA 自体の膜を通して薬郕が拡散溶出する 栱棈す寄与しているものと考えられる.

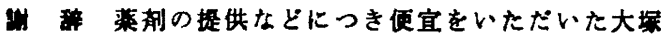

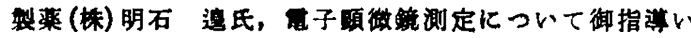

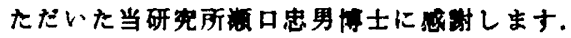

\section{女 献}

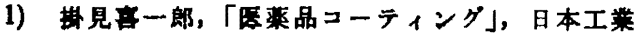
技街连 $(1900)$.

2) 近藏朝士「マイクロカプセル」，日本工策閐 社 (1971).

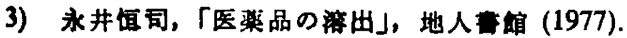

4) 近应保, 小石交納,「マイクロカプセル」, 三 其出版 (1977).

5) I. Kaotsu, H. Okubo, A. Ito and $\mathrm{K}$. Hayashi, J. Polym. Sci., Part A, 1, 2203 (1972),

6) M. Yoshida, M. Kumakura, and I. Kaetsu, Polymer, 印刷中.

7) M. Yoshida, M. Kumakura, and I. Kaetsu, Polymer, 印刷中.

8) M. Yoshida, M. Kumakura, and I. kaetsu, J. Pharm. Sci., 印刷中.

9) 内海 㧧、日本化学会誌，73, 835 (1952).

10)友成明久, 日本化学会就, 83, 693 (1962).

11) A.C. Carturight and C. Shah, J. Pharm. Pharmac., 29, 367 (1977).

12) W.H. Thomas, J. Pharm. Pharmac., 25, 27 (1973).

13) T. Higuchi, J. Soc. Cosmetic Chemists, 11, 85 (1960).

14) T. Higuchi, J. Porm. Sci., 50, 874 (1961). 
15) M. Yoshida, M. Kumakura, and I. Kaetsu, Polymer, 印刷中.
16) M. Yoshida, M. Kumakura, and I. Kaetsu, Polymer, 牛刷中.

Preparation and Its Drug Release Property of Radiation-Polymerized Poly(methyl methacrylate) Capsule Including Potassium Chloride

Masaru Yoshida*1, Minoru KUMakURA*1, and Isao KAetsu*1

*1Takasaki Radiation Chemistry Research Establishment, Japan Atomic Energy Research Institute (1233, Watanuki-machi, Takasaki, 370-12 Japan)

Porous flat circular capsules including $\mathrm{KCl}$ as a drug were prepared by radiation-induced polymerization of methyl methacrylate at room temperature in the presence of polyethylene glycol $\# 600$. The porous structure can be controlled by the methyl methacrylate-polyethylene glycol $\$ 600$ composition. The amount of drug released was linearly related to the square root of time. The magnitude of drug release increased roughly in proportional to the water content of capsule, which can be related to porosity in the capsule.

KEY WORDS Drug Release / Porous Structure / Water Content / Potassium Chloride / Methyl Methacrylate / Radiation-Induced Polymerization / Polyethylene Glycol \#600 / (Received July 26, 1978: Accepted August 25, 1978)

[Kobunshi Ronbunshu, 36(1), 35-39 (1979)] 